\title{
Does political regime matter for abnormal hoarding of international exchange reserves?
}

\author{
Viktor Koziuk \\ Economics Department, West Ukrainian National University, \\ Ukraine \\ vik.torkozink@,wunu.edu.ua \\ ORCID 0000-0002-5715-2983
}

Abstract. It is shown that political business-cycle approach to a political and institutional analysis of large exchange reserves hoarding is not full story. It is stressed, the choice of the central bank to accumulate reserves or not is not defined per se. Such choice is a consequence of political and economic consensus on the design of the mechanism of macrofinancial stability and the channels of macroeconomic adjustment. It is shown that political regimes are important proxies to understand why countries differ in incentives to hoard as well as accumulate in the long-run. At the same time, while autocracies outperforme democracies in reserves hoarding, the situation is not so simple. Institutional factors matter. This means that heterogeneity across political regimes may also play a role. The analysis of reserves distribution shows that autocracies are less homogenous. These results are substantiated by general multi-factor regression. While large hoarding is more typical of the countries with large GDP per capita, less democratic political regime and less independent central banks do not choose flexible exchange rates; i.e. only autocracy with some threshold level of development (including political and macroeconomic stability) can hoard reserves sustainably. Autocracies have better preconditions for reserves hoarding only when they are able to push a prudent macroeconomic policy. At the same time, democracies have better preconditions for alternative institutional paths, under which some alternative channels of macroeconomic adjustment could potentially arise. This finding has strong practical implication. The independence of the central banks as well as the structural reforms addressed to financial development support macroeconomic adjustment with lower level of exchange reserves.

Keywords: international exchange reserves hoarding, central banks, political regimes, financial development, quality of institutions.

JEL Classification: E58, E59, O23, Q33 


\section{INTRODUCTION}

The tendency to maintain external assets of the central banks on a scale far exceeding traditional metrics is still evident. For example, median ratio of reserve holdings exceeds IMF ARA metrics. At the same time, reserves hoarding, particularly its large amounts, is heterogeneous. There are significant differences in the ability of some countries to benefit from competitiveness and resistance to financial shocks. Heterogeneity in the ability of reserves accumulation is determined directly by political and economic factors. Such factors are based on the quality of institutions that contribute to financial development, which reduces the need for reserves to absorb shocks.

Although macroeconomic drivers of reserves accumulation are well known (openness, exchange rate regime, capital flow regime, commodity exports, etc.), political and economic factors remain a matter of debate. Political economy factors, in conjunction with the structural characteristics of the economy (e.g. resource wealth), determine the choice of macroeconomic policy regime (democracies tend to float, and autocracies vice versa) regarding reserves accumulation. On the other hand, the institutional characteristics of a country present a profile of macroeconomic policy, within which either the ability to reserves accumulation is made possible, or vice versa, the country is prone to lose them. The role of the central bank in the political economy of the reserve accumulation should reflect the broader political and economic choice of the design of the macro-financial stability mechanism.

Given this, the question of the role of political economy drivers of abnormal exchange reserves hoarding is still relevant. At the beginning of the millennium, countries with different political regimes (as a group) were closer to maintaining reserves at the level of 4 months of import. However, later autocracies reached the level of nine months of import while democracies were closer to six respectively. This mean that during the recent period some structural changes in global economy affect the countries with different political regimes in the way that required a different vision of the efficient channels of macroeconomic adjustment in a new global environment. In the paper, the idea that different political regimes form different institutional preconditions for particular macroeconomic adjustment mechanism is explored. The main hypothesis of the paper is that the central bank independence as well as the institutions that evolve from the political regime may be crucial to our understanding why countries differ in their demand for abnormal reserves. The paper demonstrates that central bank independence, flexible rates and financial development are kind of an institutional background for macroeconomic adjustment mechanism that requires less reserves hoarding in democracies. This does not mean that political business cycle approach is not relevant. This means that democracies can "invest" in institutions favourable for central bank independence and financial development, while autocracies should "invest" in the instruments supporting macroeconomic stability as a guaranty for political stability and saving the rent. At the same time, it is shown that autocracies are more heterogeneous in terms of reserve hoarding. Sustainable hoarding is thus possible in the environment when political and macroeconomic stability reinforce each other. This idea is proved with regression analysis revealing an important role of the country's GDP level as a proxy for hoarding. While the relation between hoarding and development level is viewed as normal, such relation should be viewed through the lenses of specific institutional setup in countries with different political regimes that are relevant for the central bank independence, exchange rate flexibility and financial development. The paper provides literature review and further discussion related to the problem of political regime relevance to the institutions of macroeconomic adjustment. Empirical part is based on min-max analysis for countries with a homogeneity test and multiple regression methods for deeper understanding the role of factors that affect large reserve hoarding. The final part provides the conclusion. 


\section{LITERATURE REVIEW}

International exchange reserves hoarding has been in the focus of global monetary order analysis for a long time and the global financial crisis only enhanced the interest to the issues. The growing role of global factors in the macro-financial vulnerability profile of countries has highlighted the importance of reserves as shock absorbers of capital outflows (Obstfeld et al., 2008).

There are several key explanations for hypertrophy of external assets. The new (monetary) mercantilism means that international exchange reserves are being hoarded in order to avoid the movements in an exchange rate towards the PPP, thereby supporting the export-oriented growth (Durdu et al., 2007). Some sorts of these views are financial mercantilism (Aizenman and Lee (2008)), in which international exchange reserves are seen as a factor protecting the country's financial sector from external stress, and the Bretton Woods II approach (Dooley et al., 2003, 2004). Capital inflows smoothing is further consideration to hoard the reserves. The advantages of price competition is thus the by-product attempt to reduce the vulnerability of the economy to capital flow reversals shocks (ECB, 2006; Wijnholds and Sondergaard, 2007; Choi et al., 2007). Precautionary demand or self-insurance became a very popular and influential way to understand the nature of reserve accumulation. The more vulnerable a country is to capital flow shocks, the more important is the role of reserves in ensuring macro-financial stability (Aizenman and Lee, 2008). Offsetting productivity shocks and smoothing exchange rate fluctuations in terms of financial sector weakness is also a very popular view. In the case where the latter cannot actively play the role of adjustment to shocks, and fluctuations in the exchange rate may deepen them, international exchange reserves are the best alternative (Aizenman and Riera-Crichton, 2006). In the line of continuous discussions about exchange rates and macroeconomic stability, Sanusa, Meyer and Hassan (2019) explain that the "fear of floating" drivers of reserve accumulation are still important even in the time of expended capital mobility and declined external fragility in many emerging countries. While they provide Southern African experience, such results are important form the view that the stage of development may affect the motivation for reserves accumulation. Therefore, mercantilist vs precautionary motives may be more important for countries that are at higher levels of economic development. Such conclusion helps to validate the GDP per capita variable as a proxy for reserve accumulation.

Competitive hoarding (Aizenman, 2007) is an evolutionary vision of how incentives for hoarding evolveover time. If one (more) country (ies) gains an obvious advantage over others through the reserves hoarding, others begin to follow it (them). This leads to a collective upward shift in demand for reserves, which nourishes individual demand. The country, which has lower losses from holding large reserves will win the competition in reserve accumulation, or this will be the country for which such losses are not significant from political and economic reasons.

Another view on reserves accumulation is related to the debate on the "trilemma" of goals in an open economy. The incompatibility of pursuing monetary policy in accordance with the priority of internal equilibrium, gaining financial integration benefits, and seeking to limit exchange rate fluctuations can be substantially mitigated by the possession of significant external assets. The latter makes it possible to reduce the dependence of interest rates on external shocks with a lower risk of vulnerability to reversals in capital flows, and with the simultaneous ability to smooth exchange rate fluctuations (Aizenamn et al., 2015; Aizenman et al., 2013). However this view is "macroeconomically versatile" and empirically oriented, one can see hidden political motives and more complex institutional nuances that determine monetary policy priorities.

The political and economic analysis of reserves accumulation presented in the literature is not homogeneous. 
Aizenman and Marion (2004) have shown that the following features characterise most emerging market countries: reserves accumulation, external borrowing, inelastic spending behaviour, government heterogeneity in terms of the ability to follow the principles of maximising social well-being vs rent seeking groups. A number of important political and economic issues derive from this sort of analysis. First, autocracies had better accumulated reserves. In addition to the democratic regime factor, the tendency to reserves accumulation is determined by the size of the country's economy, external vulnerability, and the IMF quota as a proxy for rapid access to international liquidity. Second, the level of corruption is inversely related to reserves. In other words, corrupted governments lose reserves and accumulate external debt, redistributing welfare to the benefit of individual rent-seeking groups. Third, governments are conditionally divided into tough - focused on maximising public welfare - and soft prone to opportunistic behaviour. If the likelihood of re-election of the former is reduced, they tend to behave like the latter, while the latter, regardless of the electoral cycle, tend to lose reserves and increase debt. In other words, under the rule of soft governments, the social maximum is reached at lower reserves, since this means reducing the amount of theft in favour of an individual group and vice versa. However, there are other empirical data. For example, Han (2006) shows that reserves accumulation may be associated with macro-financial stability and the success of the government, which will make democracies inclined to hoard them in response to a public preference.

The electoral dimension of the ability to accumulate external assets is shown in other works. Thus, the behavior of reserves is sensitive to the deployment of the electoral cycle. In emerging economies, as highlighted in Dreher and Vaubel (2009), the political business cycle is often represented by changes in reserves that offset spending increases and accelerate money supply. In particular, as highlighted in McGrath (2016), when governments change after crises, successors will be prone to increase demand for reserves as an additional toolkit to keep the macroeconomic situation favorable for re-election in the future.

Jager (2016) implements a somewhat more complex approach to electoral analysis of reserve behavior. He focuses on the political business cycle issues across the political regimes. Empirically, autocracies are more successful in reserves accumulation than democracies. There are several reasons for this. The political business cycle is stronger feature of democracies, with the corresponding consequences for the external assets accumulation. Central banks in democratic countries are more independent and more focused on price stability, with which reserves accumulation may conflict (in the absence of sterilization). Similarly, in democratic countries, the number of veto-players is higher, which does not always guarantee the elimination of preconditions for the political business cycle, but raises the likelihood that the central bank will not only be formally but actually independent.

Other types of publications focusing on motives that are ahead of demand on larger reserves in countries with different political regimes. For example, Leblang and Pepinsky (2008) showed that nature of political regime forming different motives for reserves accumulation. Democracies hoarding due to mercantilist pressure while autocracies mobilize external assets because of precautionary pressure. Democracies accumulate more reserves in the environment of strong grouping exporter's interests that may capture the monetary policy. For autocracies, countries with macroeconomic stability are more important, so they are more prone to hoard in terms of prestige and political stability. They confirm this hypothesis on the evidence of 82 developing countries. Son (2020) represents the similar conclusions on the base of analysis of 127 countries. According to Son (2020) more outward oriented elites in autocracies prefer large reserves and this effect is stronger compare with democracies with large exporting sector. At the same time, size of exporting sector is important for democracies.

In contrast to these approaches, Koziuk (2016a, 2016b, 2018) showed that both democracies and autocracies are not homogeneous due to the ability to reserves accumulation. There is also a more 
sophisticated modality for choosing the design of a macro-financial stability mechanism. Autocracies, focused on converting resource richness into payments for loyalty, are prone to fixed exchange rates, dependent central banks, significant reserves and fiscal buffers. Democracies with quality institutions are prone to independent central banks, floating rates, and financial markets developing. Both expropriation autocracies and weak democracies are equally incapable of macro-financial stability, in particular because of a macroeconomic policy conflict with the ability to international exchange reserves hoarding. These conclusions drew from the example of resource-rich countries, but can be extrapolated on a wider sample.

This view is not in contrast to business cycle approach by Jager (2016) or motives ahead of hoarding explained in Leblang and Pepinsky (2008) and Son (2020). However, we differ in understanding the role of institutions that affects nature of macroeconomic adjustment in real political environment. The initial political choice of preferable channels of macroeconomic adjustment, quality of institutions as well as social fractionalization may determine efficiency of macroeconomic policy independly from motives that are ahead of reserves demand. It must be acknowledged that a number of important issues remain unresolved. If democracies / autocracies are not homogeneous, what is the role of other institutional factors? For example, the lack of homogeneity in society can generate political conflicts that are incompatible with the reserves accumulation.

The rule of law can have a positive effect on forces that allow adaptation to shocks that do not require significant reserves. Similarly, central bank independence can be an important factor in prioritizing price stability over reserves accumulation, but equally important for protecting reserves against "capture" by rent-seeking elites. Important is the fact about reserves hoarding. As the latter generate significant fiscal losses (and additional macro-financial risks), the question of society's tolerance to them arises. Can the central bank accept such losses taking into account the political regime in which it operates? Fractionalization may also be significant. If it is not compensated by rule of law or rigid dictatorship, it could affect political instability as well as political differences. In view of the above, it is hypothesized that:

Level of development in emerging markets still important proxy for reserve hoarding but it should be viewed through the lense of how political and macroeconomic stability reinforce each over;

Political regimes form basic preconditions for particular mechanism of macroeconomic adjustment from institutional viewpoint. Central banks independence with flexible exchange rates all together with financial development have better opportunities to evolve in the democracies adherent to rule of law that doesn't require large hoarding. Autocracies may prefer alternative model of macroeconomic adjustment and preconditions for central bank independence. The same is for financial development. In this alternate setup, larger hoarding is needed to reinforce macroeconomic and financial loop of stability;

Political stability, driven by variables of social homogeneity, plays a role in minimising political conflicts that do not correspond to larger hoardings in democracies due to macroeconomic mismanagement and in autocracies because of political coups. Both political regimes are vulnerable to rent seeking by elite groups but solve the problem differently which may affect hoarding. Therefore, it is assumed that social homogeneity as a prerequisite for minimising political conflicts between competing groups for capturing political and economic rent is significant for the external assets accumulation.

The purpose of this paper is to systematize theoretical discussions around the political and economic drivers of reserves accumulation and to test empirically the above hypothesis. It is found that level of development still important for large hoarding. This means that reinforced political and macroeconomic stability that positively affected sustainable growth is a strong precondition for reserves accumulation in large amounts. At the same time, central bank independence enforced by rule of law is strong driver of motivation to maintain smaller external assets. This corresponds to the notion that better institutional quality positively affects external sustainability by exchange rate flexibility and financial development. 
However, variables of society structure are not significant, meaning that better rule of law and political preconditions for economic development serve better needs to hoarding reserves.

\section{POLITICAL AND ECONOMIC ANALYSIS OF RESERVE HOARDING}

The fact of abnormal reserves hoarding began to be actively debated after 2002. Graph 1 shows that tendency to accumulate large reserves was prominent during 1990-s and early 2000s. Moreover, in medium term perspective such phenomenon is structural, not cyclical. The speed of hoarding decelerated since 2015 events of some distress in Chinese economy and previous commodity prices correction. However, it is obvious that many countries try to maintain exchange reserves that far exceed so called ordinary needs. Deviation from the ARA metrics, introduced by IMF, is a good sign that tendency to maintaining large reserves still actual and require further attention. Over time, abnormal hoarding is not strictly viewed as a witnessing of global imbalances, but rather as a precautionary normal. Crisis episodes on that time-path contributes to incentive for further accumulation contradicting in some way with efforts of transition toward more flexible exchange rates. Since many countries gained from increased exchange rates flexibility, the role of exchange reserves demonstrates no sign of diminishing.

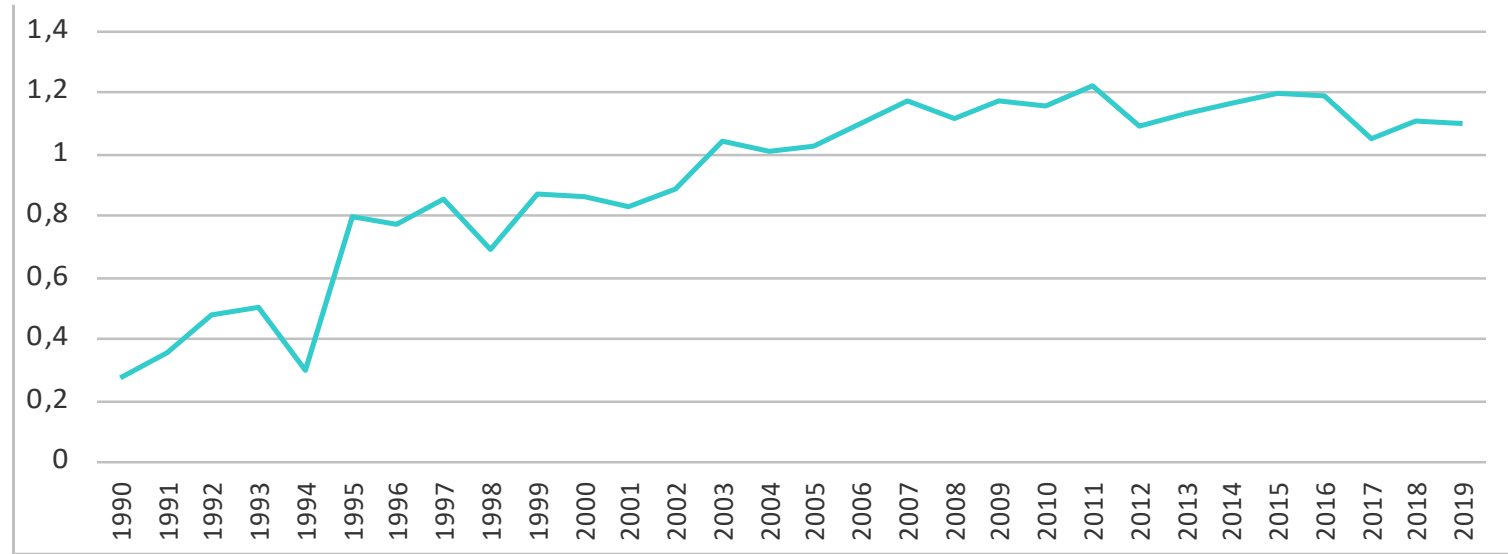

Graph 1. Median ration between Exchange reserves and relevance to ARA criteria Source: Constructed on IMF ARA Statistics.

Most Asian exporters exceeded the conventional reserve adequacy metrics at the time, covering three months of imports or covering 100\% of short-term external debt (Disyatat 2003; Gosselin and Parent, 2005). Changes in the global economy are also important, but they do not explain by themselves the significant asymmetries in the ability of different countries to accumulate external assets in large scale.

Commodity exporters have joined the tendency to accumulate large-scale reserves a little later in response to the dramatic increase in prices for natural resources. This clarification is not fundamental to the overall logic of reserves hoarding process. However, it is crucial to understand that reserves hoarding requires a favorable political and economic basis, not solely the fact of maintaining a balance of payments surplus. There are two lines of arguments here.

The first line of arguments relate to the political and economic factors that come to the fore that the large scale reserves accumulation takes place in the medium and long term. In its purest form, this is contrary to standard open-economy macroeconomic models. In other words, hoarding that enabling reserves build-up should be based on appropriate macroeconomic policy mechanism for a relatively long time. In order for such a mechanism to function relatively sustainably, several conditions are necessary. 
For both monetary and fiscal policies to comply with the principles of prudence (discipline), otherwise changes in aggregate demand induced by policy changes will inevitably affect the balance of payments and capital flows. In order for the central bank and the government to pursue prudent policies, they must be subject to some political immunity from possible changes in public perceptions of short-term priorities. Such conditions seem rather technical. However, taking into account that macroeconomic policy is implemented in the political environment, relevant to such environment institutions determine the extent to which the reserves hoarding will be demanded and viable in the political and economic sense.

The viability of external assets accumulation, in turn, is also determined by a number of institutional factors that should facilitate the inflow of foreign currency as a main direction into the country rather than the outflow. This is possible due to incentives for export-oriented growth, sectoral competitive advantages (such as Singapore or Hong Kong's financial system), or mobilized commodity rents.

Regardless of the initial motive, reserves hoarding will entail the emergence of redistributive conflict between individual groups. The presence of political formal or informal institutions in which such a conflict is neutralized is an important precondition for maintaining a focus on reserve growth over time.

Significant reserves should be associated with certain public benefit to form the basis for resolving conflict over the implementation of the hoarding policy. For democracy, this can be the macroeconomic stability in the form of better adaptability to shocks. The same applies to the autocracies, but with the notion that such reserves should serve as an additional toolkit for offsetting the exchange rate risks of the "payment for loyalty" policy. The reserves accumulation solely for the purpose of promoting geopolitical or leader ambitions, that is, without a certain relation to social welfare enhancement, is politically vulnerable. In democracies, this vulnerability stems from the competition for voters, who may be offered an alternative view of economic policy, which does not necessarily sacrifice individual consumption for the sake of large reserves as such. Autocracies are also not immune to political coups, especially when it comes to the struggle for commodity rents. Significant reserves may look like "prey".

The greater the amount of reserves diverges from conventional metrics, the greater the question of economic policy optimality is. In democracies, there must be a strong image of large-scale reserves as an important component of macro-financial stability. Accordingly, hoarding on a potentially suboptimal scale should be based on some political legitimation shared by competing social actors. In a competitive political environment, there must be rational arguments for why large-scale reserves are needed rather than just sufficient reserves. Moreover, such arguments should be relatively equally accepted by representatives of competing social groups. In autocracies, hoarding in large amount relies on a slightly different algorithm of legitimation. Significant reserves can be a "by-product" of a policy that, on the one hand, contributes to economic growth, on the other, is unlikely to be realized under another political regime. The austerity of export-oriented growth or the monopolisation of access to commodity rents as a way of preventing its wasting is typical examples. Moreover, even as they become a sign of the "success" of an autocratic regime in economic policy, the legitimation of significant reserves is transformed into a criterion for assessing whether autocracy is somehow "paying for loyalty" or turning into a tyranny of the elite.

The latter is exacerbated by the negative value of net external assets (reserves minus external liabilities) due to the voluntary redistribution of social welfare in favor of the current unproductive consumption. Similar effects are well known in references on predatory rent capture and the corresponding degradation of macroeconomic discipline (Auty, 2001; Aizenamn \& Marion, 2004; Arezki \& Bruckner, 2010).

The homogeneity of society is an important prerequisite for non-competing ethnic or social groups. Political tensions very often achieve a level that is incompatible with the implementation of economic policies conducive to reserves hoarding. In the case of democracy, the homogeneity of society eliminates 
the preconditions for a different perception of the role of social welfare reserves. Otherwise, political competition will inevitably lead to such a contest for a voter, which will result in a policy that makes it impossible to maintain large amounts of reserves. Autocracies in fragmented societies can maintain authority through a distribution of resource stock as "payment for loyalty". Otherwise, they face the problem of violence. In the latter case, the country's political landscape is unlikely to help maintain overoptimal reserves.

Large-scale reserves generate significant losses on sterilization and maintaining. The risk of their increase is compounded by the degree of real flexibility of floating exchange rate. According to Rodrick (2006) and Turner (2006), social costs of abnormal reserves are very high. It follows that the fiscal price of excess central bank external assets should be taken at the political level. Alternatively, it should not be considered as a "price" in the eyes of elite groups that tolerant to holding reserves. Or, such a price should be a better policy alternative than when it is unattainable or undesirable to initiate changes in the quality of institutions that would lead to alternative ways of adjustment to shocks, such as the development of the financial sector or a floating exchange rate.

The second line of argument relates to the problem of choosing in favor of reserves hoarding rather than the development of institutions that would be compatible with alternative mechanisms of adjustment to shocks.

Alternative channels of shocks adjustment - the development of the financial market and the flexible exchange rate - do not work by themselves separately but rather complement each other. However, for them to work as channels of macroeconomic adjustment, for which there will be some political consensus, institutional preconditions are needed. In order to get shock-absorbing function of the financial sector, it is necessary to enter a stage of financial development at which the financial system will effectively shares risks and provide access to financing. On this basis, consumption is to be smoothed in time. Institutions to protect the investors and creditors rights are required to move toward this stage of financial development. Moreover, the political system itself must be non-expropriatory in its essence. Macroeconomic stability is also required for financial development (Aizenman et al., 2015; Cihak et al., 2012; Claessens \& Laeven, 2003). Low inflation and the absence of drastic and significant changes in the macroeconomic policy are preconditions for generating returns on financial instruments consistent with the performance of the economy. Otherwise, there will be serious problems with the demand for funding.

Given that, apart from legal institutions and the basic modality of the political regime, financial stability requires price stability, the question of the central bank independence as an institutional decision comes to the fore. Equally important is how such a solution affects the ability to choose the optimal exchange rate regime. The institutional choice in favor of an independent central bank would be unpredictable if reserves hoarding was a priority. It can be assumed that, in more ordinary situations, central bank independence is more likely to help maintain a certain optimal level of reserves, if this is not contrary to price stability, but not in the case of hoarding. There are several points here.

Achieving price stability is largely based on the relevant mandate of the monetary authorities, their decision-making autonomy and political consensus that key social actors respect the central bank independence. All of this requires the rule of law. Some papers emphasize on this (Nurbayev, 2017; Hielscher \& Markwardt, 2012). Rule of law by definition limits the actions of politicians and ensures that the delegated independence of the central banks is not abolished / replaced / distorted in accordance with electoral processes or other public challenges. Moreover, the rule of law is largely achieved under a democratic political regime. However, this does not mean that, there is no specific rule of law in autocracies. For the most part, it focuses on private law. Issues governed by public law fall under a somewhat different modality of regulation, consistent with the principle of balancing the preservation of autocratic power and the provision of rent as a payment for loyalty. It is no coincidence that in autocracies 
the level of central bank independence is lower than that in democracies, but the latter are not by themselves a success guarantee of formally independent monetary authorities (Koziuk, 2016; Koziuk, 2018). The combination of the rule of law and the democratic regime brings the formal and de facto independence of the central bank closer. On the other hand, where price stability is the subject of political consensus, it is possible to achieve it even if the central banks independence is lower if there is a high level of collective confidence in society.

If the central bank is in fact independent and there is a public consensus on price stability, the international exchange reserves hoarding on a large scale becomes unlikely in the long run. This implies that central banks which are more independent are not inclined to reserves hoarding, as noted by Jager (2016). They rely on achieving price stability not through hypertrophy of external assets but sound monetary policy, which in turn is protected from political interference. Moreover, the reason why stable and long-lasting political consensuses around the priority of price stability over reserve hypertrophy is possible largely due to the political interpretation of the role of the exchange rate in ensuring macrofinancial stability.

Since reserves accumulation and exchange rate flexibility are inversely dependent, but the exchange rate is a channel of macroeconomic adjustment, political consensus on a more flexible exchange rate will take place when the cumulative benefits of doing so will outweigh the losses from the fixation. The greater the effectiveness of a flexible exchange rate is supported by a more developed financial system, the more devastating the effects of the exchange rate fixation, the faster the political consensus will be reached toward exchange rate flexibility, a policy of price stability and supporting rule of law. And within the framework of the latter, financial system participants' rights guarantee as well as guarantee of politicians' non-interference in the central bank's price stability mandate will occur. It is natural to assume that such a combination is more likely for democracies. Conversely, the more destructive for economy the exchange rate fluctuations are, the less legal institutions contribute to deepening the financial system, the more likely that political consensus will take place for greater exchange rate fixation. However, maintaining such a mix also requires appropriate macroeconomic policies. If the general weakness of institutions extends to the central bank, its ability to maintain a fixed exchange rate is limited in time. Otherwise, the influence of weak institutions on monetary policy should be eliminated. In democracies with weak institutions, this is difficult, if not impossible. Weak institutions open a wide field for competitive populism and subordination of monetary policy to electoral goals, or in some cases redistributive goals by "captured" regulator. In autocracies, this problem is solved easier. Under this political regime, there is an opportunity radically reduce political costs of budget negotiations. Moreover, this opens up another possibility in which a more dependent central bank focuses on supporting fixed exchange rate, and price stability is achieved through counter-cyclical fiscal policy. The reserves accumulation is a continuation of the link between autocratic mode, fixed rates and a weak central bank.

The case of reserves hoarding in commodity autocracies indicates why in a certain political regime more often choose a fixed rate (Aliyev, 2014; Wills \& van der Ploeg, 2014). On the one hand, the answer to this question is that this is the easiest way to ensure macroeconomic preconditions for regime loyalty by a controlled central bank. On the other hand, there is a pattern that autocracy is a way to counteract the waste of commodity rent by monopolising access to it. Furthermore, significant foreign exchange inflows to commodity exporters will be absorbed by foreign exchange reserves and sovereign wealth funds, which allows for the support of fixed exchange rates, the implementation of counter-cyclical fiscal policies, which together solve the problem of ensuring macroeconomic stability.

The tendency of commodity economies to fixed rate to some extent derived from the amplitude of fluctuations in world prices. Their negative effects are better offset by changes in reserves rather than changes in the nominal exchange rate, taking into account its impact on other sectors of the economy with 
weak financial system (Aliyev, 2012; Aliyev, 2013; Aliyev, 2014). Such weakness in commodity economies stems from the fact that extractive industries are prone to significant external borrowing. Moreover, the national financial sector cannot meet the large-scale resource requirements because of the problem of institutional quality (Kuronen, 2012). It is no coincidence that the commodity boom of the early 2000s was a turning point when autocracies were ahead of democracies hoarding large-scale reserves ( Jager, 2016). Naturally, it is the specifics of the institutions that make it possible to come to the fore, bearing in mind that the fight for rent is in the opposite direction. On the other hand, the example of Asian exporters emphasizes that the extraction factor may not be decisive.

\section{DEMOCRACIES VS AUTOCRACIES: PRELIMINARY CONSIDERATIONS AND STYLIZED FACTS}

The above analysis clearly shows that the political regime can be a good example of understanding why countries can differ not only through success in accumulating foreign exchange reserves, but also through incentives to do so on a large scale. Jager (2016) mainly emphasizes on the autocracies leadership in reserves hoarding concerning political business cycle. Leblang and Pepinsky (2008) and Son (2020) consider motives to accumulate reserves as for group interest meaning that such interests may vary across the countries with different political regimes. Such views are important, but not fit all possible cases. It is true that strict control over veto-players or budget redistribution issues support autocracies to accumulate reserves. The same is for political internalization of maintaining costs problem. However, it is very important to note that democracies as well as autocracies are not homogenous. This means that different political regimes are not incentives for hoarding and opportunities in the long run. Democracies and autocracies should generate institutional principle due to which large hoarding would be possible. This principle can go beyond the egoistic principles of interest groups. Democracy with strong rule of law may restrain egoistic interests of elite groups. While autocratic regime may introduce control elite groups and compensate them for loyalty. This also means that without strong institutional support countries with different political regimes are similarly vulnerable to the problem of exchange reserves lost. Table 1 summarizes the political and economic analysis of reserves hoarding problem in the context of alternative political regimes.

Table 1 presents that political regime is not only precondition for reserves accumulation. However, at the same time, each institutional factor support or not support large hoarding in different ways. Jager (2016) put it well, describing that electoral challenge for reserves accumulation is different across countries with different political regimes. The approach of Leblang and Pepinsky (2008) and Son (2020) is also important because it postpones the problem of group interests in reserve accumulation. Some empirical facts confirm the idea that reserves accumulation is more successful in the general autocracies.

Graph 2 demonstrates that autocracies advantage over democracies was insignificant before the financial imbalances and the era of the commodity boom. At the same time, countries with democratic regimes demonstrate more stable ratio of exchange reserves in month of import that slightly rose during two decades. Simultaneously, autocracies demonstrate dramatic difference in reserves hoarding, but mostly in times of global expansion. It is very likely that autocratic countries run with advantage in reserves accumulation mostly in the case of commodity windfalls. This mean that commodity prices, interacting with specific political and institutional dimension of resource abundance, support the idea that autocratic regimes are better tailored for reserves accumulation. However, this statement also means that not the political regime itself play key role. Politically vulnerable autocracy may lose reserves during times of political instability and resource richness may support that due to bigger temptation of competing groups to monopolize the rent. 
Table 1

Institutional dimension of reserves hoarding across the political regimes

\begin{tabular}{|c|c|c|}
\hline & Autocracies & Democracies \\
\hline $\begin{array}{l}\text { The motive of } \\
\text { hoarding }\end{array}$ & $\begin{array}{l}\text { An "by-product" of economic policy that } \\
\text { makes it possible to "pay for loyalty", } \\
\text { which subsequently becomes a symbol of } \\
\text { regime power }\end{array}$ & $\begin{array}{l}\text { Creating an "airbag" turns into an image of a } \\
\text { key element of macro-financial stability, for } \\
\text { which there is relative public agreement }\end{array}$ \\
\hline Electoral cycle & $\begin{array}{l}\text { Sensitive dynamics of reserves volume to } \\
\text { the electoral cycle occurs only in some } \\
\text { cases }\end{array}$ & $\begin{array}{l}\text { The sensitivity of reserves to the electoral } \\
\text { cycle is inversely proportional to the power of } \\
\text { public consent to their key importance as a } \\
\text { macro-financial buffer }\end{array}$ \\
\hline $\begin{array}{l}\text { The role of the } \\
\text { exchange rate }\end{array}$ & $\begin{array}{l}\text { As autocracies gravitate to fixed rates, the } \\
\text { reserves accumulation replaces the } \\
\text { process of macroeconomic adjustment }\end{array}$ & $\begin{array}{l}\text { As democracies are more typical of a floating } \\
\text { exchange rate, reserves play the role of an } \\
\text { optimal mix of different channels of } \\
\text { macroeconomic adjustment }\end{array}$ \\
\hline $\begin{array}{l}\text { The role of financial } \\
\text { sector }\end{array}$ & $\begin{array}{l}\text { The financial sector can act as a shock } \\
\text { absorber in some cases where autocracy } \\
\text { creates specific institutions for the } \\
\text { development of the financial system. In } \\
\text { general, the relative weakness of the } \\
\text { financial sector leads to an alternative } \\
\text { macroeconomic adjustment in the form } \\
\text { of fluctuations in reserves or changes in } \\
\text { fiscal buffer stocks }\end{array}$ & $\begin{array}{l}\text { A strong financial sector is able to act as a } \\
\text { shock absorber, but this requires high quality } \\
\text { institutions, which together allow for } \\
\text { alternative macroeconomic adjustment. In } \\
\text { other cases, reserves offset institutional } \\
\text { failures of financial development. In the case } \\
\text { of weak institutions, the country is unable to } \\
\text { either develop the financial sector or hoard } \\
\text { reserves. }\end{array}$ \\
\hline $\begin{array}{l}\text { The role of central } \\
\text { bank independence }\end{array}$ & $\begin{array}{l}\text { The central bank institutional weakness in } \\
\text { maintaining price stability is offset by an } \\
\text { active fiscal policy (fiscal buffers). The } \\
\text { central bank is subordinated to the needs } \\
\text { of maintaining a stable exchange rate and } \\
\text { appropriate management of significant } \\
\text { reserves }\end{array}$ & $\begin{array}{l}\text { In its purest form, an institutionally weak } \\
\text { central bank is not able to "protect" reserves } \\
\text { in case of irresponsible government policy. } \\
\text { On the other hand, a strong central bank can } \\
\text { guarantee price stability with a lower volume } \\
\text { of reserves. To hoard reserves in large } \\
\text { amount, a specific combination of the } \\
\text { "metered" independence of the central bank } \\
\text { with the political prerequisites for a prudent } \\
\text { macroeconomic policy is required }\end{array}$ \\
\hline Fiscal losses & $\begin{array}{l}\text { They may be ignored by the absence of an } \\
\text { alternative political view on economic } \\
\text { policy }\end{array}$ & $\begin{array}{l}\text { May be accepted if there is a general tolerance } \\
\text { for reserve hypertrophy }\end{array}$ \\
\hline Social fragmentation & $\begin{array}{l}\text { It is neutralized by the specificity of the } \\
\text { political regime and its ability to "pay for } \\
\text { loyalty". In other cases, significant } \\
\text { reserves can turn into a "prey" of } \\
\text { competing social fractions }\end{array}$ & $\begin{array}{l}\text { It complicates the reserves hoarding, since } \\
\text { the redistributive effects and fiscal losses of } \\
\text { such policies are easily transformed into a } \\
\text { toolkit for political struggle between } \\
\text { conflicting social groups }\end{array}$ \\
\hline Resource wealth & $\begin{array}{l}\text { It is a basic precondition for reserves } \\
\text { hypertrophy. Sovereign wealth funds are } \\
\text { a functional continuation of an active } \\
\text { fiscal policy }\end{array}$ & $\begin{array}{l}\text { It is a basic precondition for reserves } \\
\text { hypertrophy only when reaching a certain level } \\
\text { of institutional maturity. Creating a sovereign } \\
\text { wealth fund may be a better alternative }\end{array}$ \\
\hline $\begin{array}{l}\text { Export-oriented } \\
\text { growth }\end{array}$ & $\begin{array}{l}\text { It is an important precondition for } \\
\text { reserves hypertrophy, as it is easily made } \\
\text { possible by the political regime, which } \\
\text { limits political requests for greater current } \\
\text { consumption }\end{array}$ & $\begin{array}{l}\text { It can only lead to hoarding if there is strong } \\
\text { public agreement to abstain from current } \\
\text { consumption. However, this situation is } \\
\text { always vulnerable to alternative options for } \\
\text { stimulating growth in a competitive political } \\
\text { environment, making reserves hypertrophy } \\
\text { unlikely }\end{array}$ \\
\hline
\end{tabular}

Source: Grouped by author. 
While Jager (2016) used reserves to GDP metrics, graph 2 demonstrates another way to express the similar tendency on the data of 164 countries.

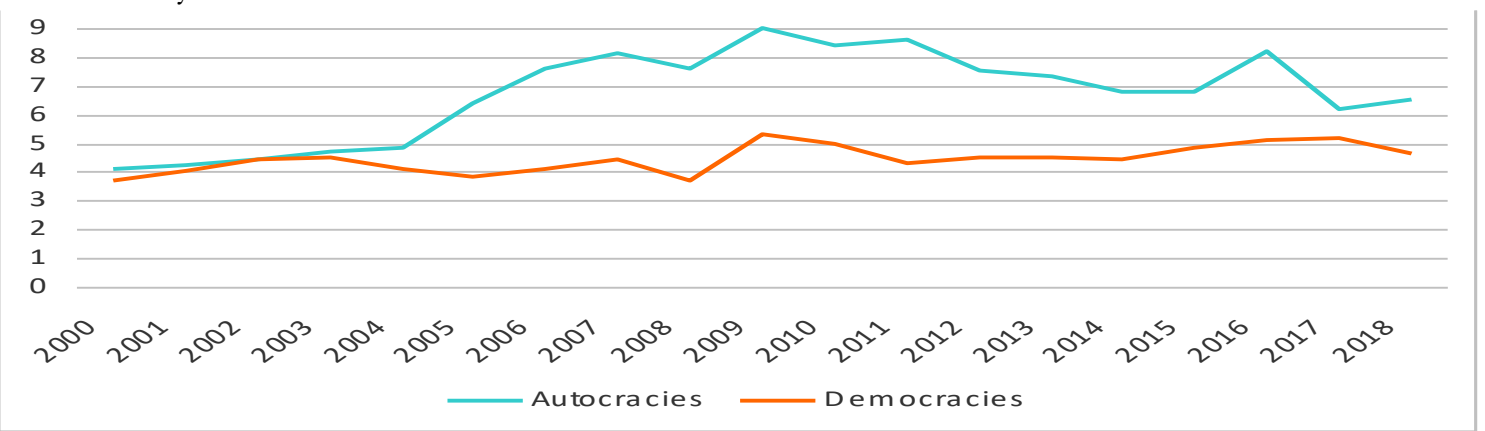

\section{Graph 2. Exchange reserves in month of import across different political regimes}

Source: Authors calculations based on IMF Statistics. Countries are divided on different groups according to Democracy Index. Higher score than 4 means the democracy.

While it is important to recognize that political regimes are not preconditions for reserves hoarding, Graphs 3 and 4 show that heterogeneity of the democracies and autocracies is important. Min-max analysis demonstrates some differences in reserves distribution across the countries with different political regimes.

Graphs 3-4 demonstrate some novelty on the area of reserves accumulation across different political regimes. At first, democracies were relatively more successful before the commodity boom. On initial stages of hoarding process, they were much closer to autocracies as it is shown in graph 2. However, evolving, process of reserve accumulation went different ways in two groups of countries. Democracies are less volatile in that regard. This also supports the idea of commodity prices role. Secondly, democracies are more homogenous. Distance between minimum, maximum and average levels of reserves accumulation is much smaller than in autocracies. This means that democratic political regime is more open for searching for alternative adjustment channels and more sensitive to costs of maintaining. Minimum levels of reserves are higher in democracies. While average levels are similar in both cases, such levels only in particular years after global financial crisis are higher in autocracies substantially. However, maximum levels are dramatically higher in autocracies.

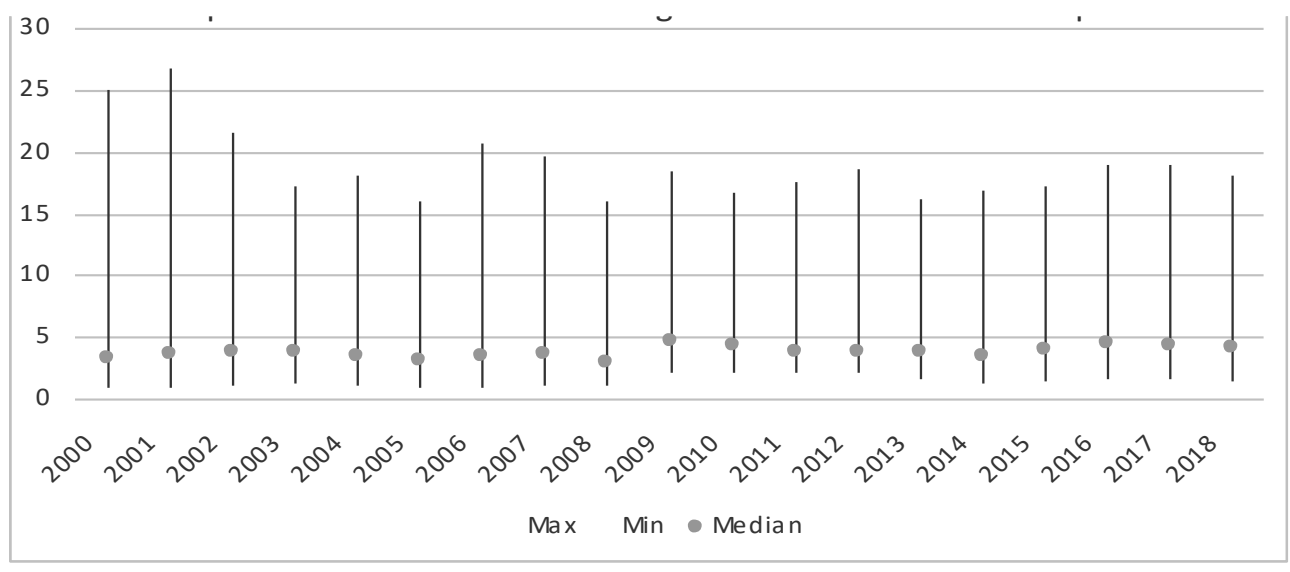

Figure 3. Democracies. Exchange reserves in month of import

Source: Authors calculations based on IMF Statistics. Countries are divided on different groups according to Democracy Index. Higher score than 4 means the democracy. 


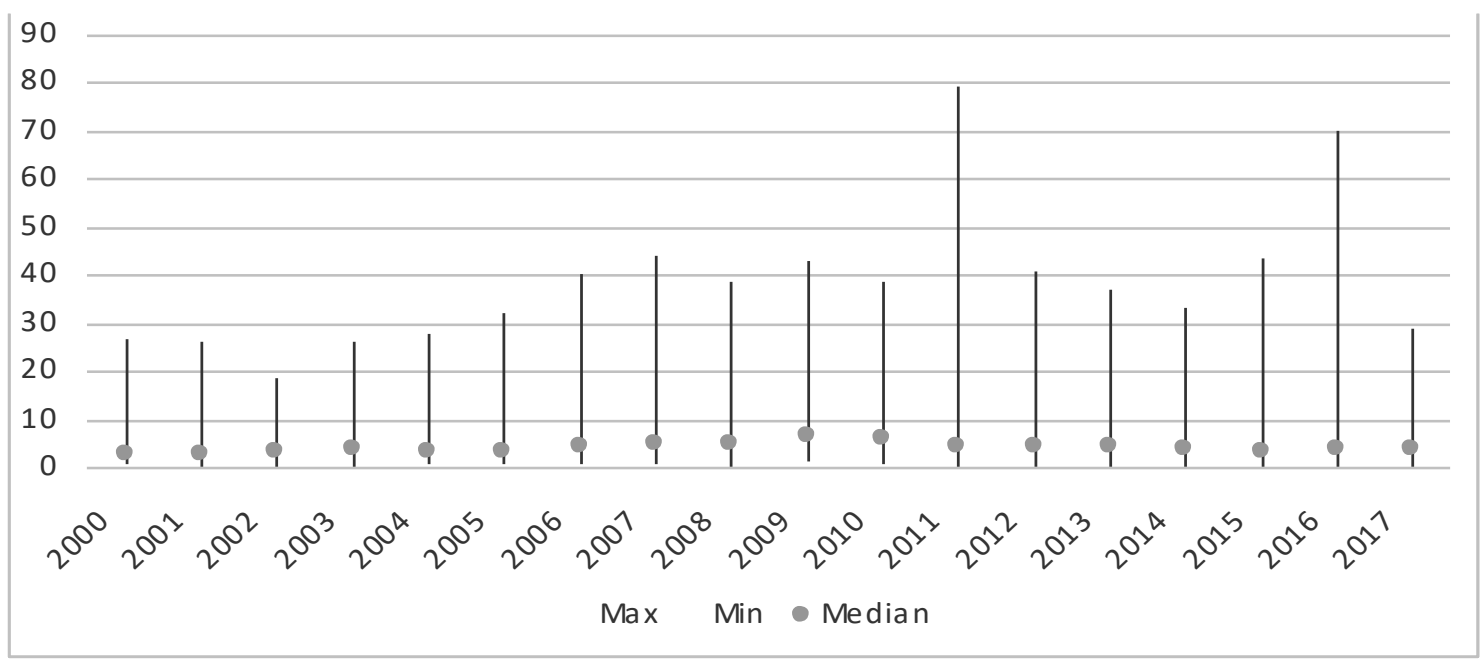

Figure 4. Autocracies. Exchange reserves in month of import

Source: Authors calculations based on IMF Statistics. Countries are divided on different groups according to Democracy Index. Higher score than 4 means the democracy.

Such evidence is a strong argument that institutions are important. Weak and expropriation-oriented autocracy cannot accumulate reserves as well as weak democracy vulnerable to populism. Simultaneously, large hoarding is also possible in autocracies due to the peculiarities of the external adjustment mechanism, the institutional set-up of central banks or the inconsistency with the content of the problem of expenditures. These considerations are supported by more formal proofs in next part of the paper.

\section{METHODOLOGY: AN EVALUATION OF RESERVES ACCUMULATION DRIVERS}

Some heterogeneity across countries described in previous chapter requires deeper further analysis. Patterns of uneven distribution of reserves among the countries are better understood using the institutional powers of attorney as independed variables. Simultaneously, there are no consensus in references which variable is a good proxy for abnormal accumulation.

Empirical research does not show agreement on which variable is chosen to be dependent. In some cases, these are reserves per unit of population, reserves to M2, or reserves to GDP (Jager, 2016; Han, 2006; Aizenman \& Marion, 2004). The same for independent variables, the choice of which is dictated by specific research needs. In order to emphasize the fact of hoarding, constructing a multifactor regression model (tested in nine specifications, table 2), and the independent variable is specified as "reserves in months of import - 3" and "ratio between reserves and short-term external debt - 100\%". In both cases, the source of data is World Development Indicators provided by World Bank. The latter variable is hypothetically better suited to the idea of precautionary demand, but is available in far fewer countries. It was used to test the basic equation, which is generally similar, so these results are not shown. For reasons of statistical validity, the indicator "reserves in months of imports - 3" was chosen because it covers a much larger number of countries. The sample covers 164 countries for the period 2000-2018. Availability of data is important factor of time length selection.

The choice of independent variables in this paper directly follows from the theoretical considerations. Such considerations are derived from assumptions about the potential influence of political-economic / institutional factors on the ability of central banks to accumulate external assets. Because of this, the 
selected dependent variable is tested for relation with composition of independent variables that are not presented in previous studies.

Controlled independent variables are:

Ln GDP per capita. According to most theoretical explorations, it is assumed that reserves hoarding requires a certain scale effect. Moreover, many poor countries do not have the ability to reserves accumulation due to the weakness of institutions and the atrophy of foreign currency inflows. Economic development is also an indirect indicator of the political and macroeconomic loop of stability. Accordingly, a positive correlation is expected between the GDP per capita and the selected dependent variable. Logarithmisation is performed to neutralize the effect of significant variation in the sample. Data source - World Bank Statistics (World Development Indicators);

FO - financial openness. Theoretically, the more financially open a country is, the more flexible is an exchange rate, the more capital flows are adjusted to domestic macroeconomic processes, the less likely it is to be vulnerable to significant capital flow shocks, which reduces demand for reserves. The relationship between financial openness and the dependent variable is expected to be negative. The normalized ChinnIto Index value was selected from the Aizenman-Chinn-Ito Trilemma Statistics as statistical quantitative indicator of financial openness;

Ln FD - financial depth. It is assumed that the deeper the financial system is, the better it absorbs shocks, reducing demand for reserves. This variable is represented by the logarithmic indicator of the ratio of domestic credit to private sector to GDP according to World Bank Statistics (World Development Indicators). Although this variable does not fully reflect financial developments and may not take into account the financial system model (market-based/banking-based), this indicator is more representative for most low- and middle-income countries. The theoretically predictable is inverse correlation;

Ln Com - share of non-industrial exports. This variable is selected as an indicator for resource wealth, with the adjustment that the nature of the vulnerability is similar for countries with developed agrarian sectors. Data source - World Bank Statistics (World Development Indicators). Theoretically, resource wealth should be directly related to the demand for reserves, but this assumption is not rigid, since it requires additional institutional considerations. Furthermore, not all countries that have hoarded reserves are commodity exporters. The Economic Complexity Index (ECI) variable is used for additional control. As commodity specialization is inversely related to economic complexity, it is likely that the latter may better explain the ability to accumulate reserves in countries not burdened with resource wealth. In this case, the connection is assumed;

DI - political mode variable represented by the Democracy Index, calculated by the Heritage Foundation. An index value of $<4$ means an autocratic regime, $>4$ means a democratic regime (with different variants of the quality of democracy, which, however, is not the focus of the research). The link may theoretically be direct and inverse depending on additional institutional considerations, although the coefficient is expected to be negative in other empirical evidence.

The variables of the institutional analysis are presented as follows:

RL - rule of law index. An indicator of the rule of law on World Bank Statistics (World Development Indicators) aims to represent the quality of institutions, as the country is most general but capacious institutional characteristic. The link is tested directly (although its direction can theoretically be both direct and inverse) and in conjunction with the central bank independence index;

FE - indicator for social heterogeneity. This variable is presented as the Fractionalized Elites subindex of the Fragile State Index, which attests to the elite fragmentation or the distance between the interests of different social groups, pointing to potential tensions in society caused by its socio-economic heterogeneity. The Peace Fund calculates this indicator. It is suggested that a lack of homogeneity in society should weaken the ability to reserves accumulation; 
EF - alternative indicator for social heterogeneity. In this case, it is an indicator of ethnic fragmentation calculated to analyze the impact of potential interethnic tensions on economic processes (Alesina et al., 2002). Similarly, the likely conflicts caused by a lack of ethnic homogeneity limit the ability to reserves accumulation;

GMT - GMT index of central bank independence has been updated for more countries (Crowe and Meade, 2008). Given the theoretical debate, it is assumed that it should be inversely related to the dependent variable. The interaction of this indicator with the rule of law and the exchange rate flexibility index (ExRF), which is a normalized value of exchange rate volatility from statistical base the AizenmanChinn-Ito Trilemma Statistics, is additionally tested to assess the actual independence of the central bank. The exchange rate variable is not selected directly for testing because of the potential for nonlinear links to the reserves accumulation process. However, in conjunction with central bank independence, it better reflects the profile of the monetary regime, which should see a lower demand for foreign exchange reserves.

\section{EMPIRICAL RESULTS AND DISCUSSION}

Using simple multy-factor regression model we obtain the results that in general confirms the general logic of introduced assumptions. However, some empirical results are not in line with predictions mostly due to statistical quality of relations. Nevertheless, as it would be shown, such unexpected results could be considered as not contradictive with institutional approach explored in the paper.

Table 2 presents regression analysis results.

Based on data analysis results in table 2 the following generalizations can be made.

There is the undeniable fact that the ability to reserves hoarding is very sensitive to the scale effect. The economy of scale variable has a theoretically predictable sign in all specifications. Moreover, all specifications have a statistically significant links except one. Theoretically, this pattern can be explained by the fact that the economy of scale indirectly reflects a specific reduction in the costs of sterilization and other negative manifestations of reserves hypertrophy. This conclusion does not mean that the ability to accumulate reserves is determined solely by the level of economic development. Rather, regression analysis results indicate that the excess reserves are more sensitive to the level of economic development in the sense that it provides a stable and significant amount of net currency inflows. This means that only countries that are politically and macroeconomically resilient can accumulate large reserves. Taking into account that different countries from political regime side form the group, such results also indicate that in different political regimes different factors constitute macroeconomic and political loop of stability that positively affect reserves accumulations.

Financial openness demonstrated a theoretically predicted inverse relationship with the dependent variable, although its statistical significance is insufficient. However, indicator of commodity wealth has not shown a direct relation, as could be expected. With the exception of one specification, the statistical significance of this variable is also insufficient in all cases. It can be assumed that structural factors are generally, important in explaining a country's ability to reserves hoarding but correcting for political and economic features. This is clearly seen in the case of credit depth. It has the correct direction of relation in all specifications with the exception of two, but not all statistically significant. Specification (3) is interesting. 
Table 2

Regression analysis results

\begin{tabular}{|c|c|c|c|c|c|c|c|c|c|}
\hline & (1) & (2) & (3) & (4) & (5) & (6) & (7) & (8) & (9) \\
\hline $\begin{array}{l}\text { Ln GDP } \\
\text { per capita }\end{array}$ & $\begin{array}{l}1,36798 \\
(2,8846) \\
0,00467\end{array}$ & $\begin{array}{l}1,07927 \\
(2,4946) \\
0,01388\end{array}$ & $\begin{array}{l}1,20756 \\
(2,1827) \\
0,03128\end{array}$ & $\begin{array}{c}0,37911 \\
(0,7105) \\
0,47941\end{array}$ & $\begin{array}{l}1,51766 \\
(3,0591) \\
0,00276\end{array}$ & $\begin{array}{l}1,42689 \\
(2,951) \\
0,00386\end{array}$ & $\begin{array}{l}1,46304 \\
(3,1031) \\
0,00241\end{array}$ & $\begin{array}{l}0,6351 \\
(1,5267) \\
0,13066\end{array}$ & $\begin{array}{l}1,30922 \\
(3,16823) \\
0,001961\end{array}$ \\
\hline $\mathrm{FO}$ & $\begin{array}{l}-2,04849 \\
(-1,3688) \\
0,17368\end{array}$ & $\begin{array}{l}-1,71269 \\
(-1,2811) \\
0,20247\end{array}$ & $\begin{array}{l}-1,01332 \\
(-0,5845) \\
0,56012\end{array}$ & $\begin{array}{l}-0,3709 \\
(-0,273) \\
0,7857\end{array}$ & $\begin{array}{l}-1,8434 \\
(-1,221) \\
0,22451\end{array}$ & $\begin{array}{l}-2,1805 \\
(-1,395) \\
0,16565\end{array}$ & $\begin{array}{l}-1,772 \\
(-1,192) \\
0,23571\end{array}$ & $\begin{array}{l}-0,0638 \\
(-0,050) \\
0,96024\end{array}$ & $\begin{array}{l}-1,72607 \\
(-1,1669) \\
0,24562\end{array}$ \\
\hline Ln FD & $\begin{array}{l}-1,11198 \\
(-1,4323) \\
0,15472\end{array}$ & $\begin{array}{l}-0,30585 \\
(-0,4407) \\
0,66016\end{array}$ & $\begin{array}{l}0,17165 \\
(0,19252) \\
0,84771\end{array}$ & $\begin{array}{l}0,0147 \\
(0,0198) \\
0,98424\end{array}$ & $\begin{array}{l}-1,1332 \\
(-1,459) \\
0,14714\end{array}$ & $\begin{array}{l}-0,9942 \\
(-1,237) \\
0,21872\end{array}$ & $\begin{array}{l}-1,3364 \\
(-1,721) \\
0,0879\end{array}$ & & \\
\hline Ln Com & $\begin{array}{l}-0,90184 \\
(-1,3909) \\
0,16691\end{array}$ & & & $\begin{array}{l}-0,9329 \\
(-1,597) \\
0,11411\end{array}$ & $\begin{array}{l}-0,8206 \\
(-1,257) \\
0,21149 \\
\end{array}$ & $\begin{array}{l}-1,0349 \\
(-1,531) \\
0,12849\end{array}$ & $\begin{array}{l}-1,0494 \\
(-1,625) \\
0,10684 \\
\end{array}$ & $\begin{array}{l}-1,1002 \\
(-2,131) \\
0,03607\end{array}$ & $\begin{array}{l}-0,93862 \\
(-1,509) \\
0,133901\end{array}$ \\
\hline ECI & & & $\begin{array}{l}-0,42011 \\
(-0,5443) \\
0,58741\end{array}$ & & & & & & \\
\hline DI & $\begin{array}{l}-0,90949 \\
(-3,2749) \\
0,00139\end{array}$ & $\begin{array}{l}-0,73942 \\
(-2,8239) \\
0,00550\end{array}$ & $\begin{array}{l}-0,85014 \\
(-2,6031) \\
0,01058\end{array}$ & $\begin{array}{l}-0,3121 \\
(-0,799) \\
0,42631\end{array}$ & $\begin{array}{l}-0,6883 \\
(-1,957) \\
0,05273\end{array}$ & $\begin{array}{l}-0,8971 \\
(-3,182) \\
0,00189\end{array}$ & $\begin{array}{l}-0,7329 \\
(-2,531) \\
0,01273\end{array}$ & $\begin{array}{l}-0,1985 \\
(-0,611) \\
0,54265\end{array}$ & $\begin{array}{l}-0,73078 \\
(-2,527) \\
0,01284\end{array}$ \\
\hline RL & & & & $\begin{array}{l}-5,9875 \\
(-1,117) \\
0,2672\end{array}$ & & & & & \\
\hline FE & & & & & $\begin{array}{l}0,29636 \\
(1,0249) \\
0,30752\end{array}$ & & & & \\
\hline $\mathrm{EF}$ & & & & & & $\begin{array}{l}1,51139 \\
(0,7549) \\
0,45189\end{array}$ & & & \\
\hline GMT & & & & & & & $\begin{array}{l}-4,5379 \\
(-1,917) \\
0,05778 \\
\end{array}$ & & \\
\hline $\begin{array}{l}\text { GMT* } \\
\text { RofL }\end{array}$ & & & & & & & & $\begin{array}{l}-10,204 \\
(-3,384) \\
0,00109\end{array}$ & \\
\hline $\begin{array}{l}\text { GMT* } \\
\text { ExRF }\end{array}$ & & & & & & & & & $\begin{array}{l}-1,40767 \\
(-2,3893) \\
0,018494\end{array}$ \\
\hline Intercept & $\begin{array}{l}14,00840 \\
(3,3389) \\
0,001131\end{array}$ & $\begin{array}{l}6,68796 \\
(3,3966) \\
0,000909\end{array}$ & $\begin{array}{l}5,02533 \\
(1,6713) \\
0,09764\end{array}$ & $\begin{array}{l}10,2204 \\
(2,4622) \\
0,01593\end{array}$ & $\begin{array}{l}10,2469 \\
(1,8386) \\
0,06856\end{array}$ & $\begin{array}{c}13,3754 \\
(3,0923) \\
0,00249\end{array}$ & $\begin{array}{l}16,7764 \\
(3,8196) \\
0,00022\end{array}$ & $\begin{array}{l}9,9503 \\
(4,0031) \\
0,00014\end{array}$ & $\begin{array}{l}12,1308 \\
(3,7887) \\
0,00024\end{array}$ \\
\hline $\mathrm{R}^{2}$ & 0,1488 & 0,1013 & 0,1071 & 0,107 & 0,1565 & 0,1522 & 0,1752 & 0,2041 & 0,1738 \\
\hline $\begin{array}{l}\text { F } \\
\text { Statistics }\end{array}$ & $\begin{array}{l}F(5,116) \\
=4,0559\end{array}$ & $\begin{array}{l}\mathrm{F}(4,128) \\
=3,6053\end{array}$ & $\begin{array}{l}F(5,105) \\
=2,5198\end{array}$ & $\begin{array}{l}\mathrm{F}(6,81) \\
=1,619\end{array}$ & $\begin{array}{l}\mathrm{F}(6,115) \\
=3,557\end{array}$ & $\begin{array}{l}F(6,114) \\
=3,412\end{array}$ & $\begin{array}{c}\mathrm{F}(6,115) \\
=4,07\end{array}$ & $\begin{array}{l}F(5,82) \\
=4,205\end{array}$ & $\begin{array}{l}\mathrm{F}(5,116) \\
=4,900\end{array}$ \\
\hline
\end{tabular}

Source: Calculated using the package STATISTICA.

The use of the Economic Complexity Index as an indicator of resource richness affects changes in sign in case of the credit depth indicator. This may indicate that the more diversified the economy, the more advanced the banking system needs to be "protected" by reserves. Such an interpretation is close to the phenomenon of financial mercantilism, as pointed by Aizenman and Lee (2008). The same can be seen in specification (4) with indicator of the rule of law. Countries with low quality of institutions that 
seek to deepen the financial system are increasing demand for reserves. However, in these specific cases, the statistical links significance is insufficient. Nevertheless, this does not exclude the importance for some countries of the motive for the accumulation associated with the policy of financial protectionism. Simultaneuosly, such findings rather support discussion with results presented in Leblang and Pepinsky (2008) and Son (2020). Low significance of structure of economic factor in contradiction to exportinterest groups can influence the political agenda before reserves accumulation.

The political regime is a fundamental factor that determines the ability to hoard reserves in large amount. The democracy index is in inverse relation with dependent variable in all specifications, and this relationship is statistically significant except for the specification (8). The ability of autocracies to reserves hoarding, however, is not explained solely by the commodity factor, as might be expected. Most likely, in favor to autocracies play a certain set of factors, namely: insensitivity of reserves to the political business cycle; implicit guarantees of a stable macroeconomic performance; ability to build counter-cyclical fiscal mechanisms without costs for budget negotiations; a selective approach to investor rights guarantees; the need for reserves to offset the risks of balance of payments deterioration as a result of "payment for loyalty" policy. It is likely, that institutional factors of potential inability to reserves accumulation like ethnic fragmentation or the competing elite groups are offset by the ability of autocracies to make the rational macroeconomic policies. This conclusion does not deny the fact that often autocracies in heterogeneous societies tend to seek rent and expropriate political competitors. Political vulnerability to coups and the inability to pursue prudent macroeconomic policy could be precondition for social discontent. Autocratic regimes that are focused on a particular kind of social inclusion are most interested in reserves hypertrophy because it is their kind of success in offsetting all other institutional imperfections.

The rule of law has not directly demonstrated a significant impact on the ability to reserves hoarding. There is an inverse relationship between the rule of law index and the dependent variable, but it is not statistically significant. However, the more interesting fact is that the inclusion of the RL variable dramatically degrades the statistical significance of all others. Specification (4) is the only one in which no variable, despite the correct signs, reached statistical significance. This phenomenon can be explained by more complex forms of interaction between, for example, the political regime and the rule of law, or between the latter and the ability to convert a net currency inflows into economic development.

Central bank independence is also key factor to understanding the propensity to reserves accumulation. As can be seen from specification (7), independent central banks are indeed less likely to hold significant reserves. The GMT variable is very close to statistical significance. Even more eloquent is the actual independence expressed by the interaction of the GMT and Rule of Law variables. In the case of specification (8), strong inverse relationship is observed which reduces the statistical significance of economic development and political regimes, but enhances significance of strong inverse relationship between reserves accumulation and resource wealth. This can be explained by the fact that, in the case of actual independence, central banks focused on price stability are not prone to reserve hypertrophy, regardless of the level of economic development, export structure and the nature of the political regime. This is precisely the indirect manifestation of the rule of law. The actual independence of the central bank is the starting point for the development of institutional trajectories, within which the role of alternative to exchange reserves channels of macroeconomic adjustment is increased. Specification (9) confirms this view. Independent central banks pursuing a policy of actual exchange rate floating do not show a tendency to reserves hoarding. The strong political consensus around such practices stems from the ability to create an institutional basis for alternative adjustment to shocks. It also indirectly confirms the tendency of autocracies to have more dependent central banks, which are far from the policy of exchange rate flexibility. 
The regression analysis results confirm that political-economic factors and institutional parameters are important in explaining options for countries to choose the mechanisms of macroeconomic adjustment. The priority of international exchange reserves hoarding is determined not only by the optimal exchange rate flexibility with restrictions in the form of structural features of the economy. This priority also reflects how stable the political and economic consensus is on alternative adjustment options. Accumulation priority is updated with institutional constraints that cannot be overcome within a given political structure. In other words, this is a case where the stability of the political regime relies on a variant of macroeconomic adjustment that does not require institutional changes that tend to compromise the stability of such a regime. Autocracies create the best set of political and economic preconditions for reserves hypertrophy. Whereas democracies allow for the emergence of such institutional trajectories, which create opportunities for alternative macroeconomic adjustment options that do not conflict with the nature of the democratic regime. Central bank independence, exchange rate flexibility and less pronounced dependence on resource wealth are key factors in why democracies are less likely to hoard reserves. The political business cycle and the sensitivity of reserves to it is more an explanation of why reserves change in volumes rather than why they hoard in large amount. Results extrapolation of emerging markets suggests that even if the current level of reserves is lower than optimal, further accumulation of them cannot substitute the needs to radically improve the quality of institutions as a precondition for the development of the financial system and better adaptability to exchange rate fluctuations.

\section{CONCLUSIONS}

Traditional theoretical approaches explain the reserves hypertrophy in the categories of monetary mercantilism, self-insurance, competitive hoarding, etc. In political and economic analysis, the focus is on which of the political regimes better reflects the ability to accumulate external assets. The vulnerability of democracies to the political business cycle and the inability of independent central banks to make such accumulation are most often argued.

The limitation of either the political business cycle approach or the preferences of the central bank is that they ignore several fundamental points: the status of the central bank is not an institutionally given, but is one of the institutional choices; macroeconomic adjustment channels alternative to the reserves accumulation can be developed with the relevant political and economic choice to build institutional preconditions for financial development and less painful exchange rate fluctuations; the structural characteristics of the economy and society can play an important role in choosing the optimal macrofinancial stability design as they determine the profile of political and economic consensus on the central bank priorities; the political environment determines the degree of non-acceptance of the fiscal burden of excess reserves sterilization, etc.

It is empirically confirmed that the propensity for reserve hypertrophy is determined by the level of economic development, the autocracy type of the political regime, and the choice of less dependent central banks in favor of lower exchange rate flexibility. At the same time, the actual independence of the monetary authorities and the monetary policy's focus on price stability and exchange rate flexibility reduce the demand for excess reserves. The direct influence of the rule of law, ethnic heterogeneity and group fragmentation of society does not play a significant role if the autocratic regime is capable of pursuing a prudent macroeconomic policy, which is also a manifestation of the net currency inflows and, accordingly, the reserves accumulation. In democracies, there is a tendency for strong demand on reserves accumulation where a certain level of financial depth has already been reached that requires "protection" from institutional imperfections. At the same time, opting for an independent central bank and a flexible exchange rate regime requires that democracies focus on institutional changes that enhance financial 
development. For emerging markets, the demand for reserves should not be considered as a compensator for the insufficient quality of institutions that impede the deepening of the financial system.

\section{REFERENCES}

Aizenman, J. (2007). Large hoarding of international reserves and the emerging global economic architecture. NBER Working paper, 13277, 3-19. https://doi.org/10.3386/w13277

Aizenman, J., Cheung, Y., \& Ito, H. (2015). International reserves before and after the global crisis: is there no end of hoarding?. Journal of International Money and Finance, 52, 102-126. doi:10.1016/j.jimonfin.2014.11.015

Aizenman J., Chinn M., \& Ito H. (2013). "Impossible Trinity" Hypothesis in an Era of Global Imbalances: Measurement and Testing. Review of International Economics, 21(3), 447-458. https://doi.org/10.1111/roie.12047

Aizenman J., Jinjarak Y., \& Park D. (2015). Financial development and output growth in developing Asia and Latin America: a comparative sectoral analysis. NBER Working Paper, 20917, 1-37. doi:10.3386/w20917

Aizenman J., Lee J. (2008). Financial versus monetary mercantilism: long-run view of large international reserves hoarding. The World Economy, 31(5), 1-22. https://doi.org/10.1111/j.1467-9701.2008.01095.x

Aizenman J., Marion N. (2004). international reserve holding with sovereign risk and costly tax collection. Economic Journal, 17, 370-400. https://doi.org/10.2139/ssrn.1288138

Aizenman J., \& Riera-Crichton D. (2006). Real exchange rate and international reserves in the era of growing financial and trade integration. NBER Working Paper, 12363, 1-36. https://doi.org/10.3386/w12363

Alesina A., Devleeschauwer A., \& Easterly W. (2002). Fractionalization. NBER Working Paper, 9411, 1-72. https://doi.org/10.2139/ssrn.319762

Aliyev R. (2013). Procyclicality in resource-rich countries. Ministry of Finance of the Czech Republic Working Paper, 1/2013, 1-24. https://www.mfcr.cz/en/about-ministry/research/2013/fiscal-policy-procyclicality-inresource-36571

Aliyev R. (2012). Monetary policy in resource-rich developing economies. CERGE-EI Working Papers, 466, 1-49. https://www.cerge-ei.cz/pdf/wp/Wp466.pdf

Aliyev R. (2014). Determinants of the choice of exchange rate regime in resource-rich countries. CERGE-EI Working Papers, 527, 1-36. https://dx.doi.org/10.2139/ssm.2856953

Arezki R., Brückner M. (2012).Commodity windfalls, polarization, and net foreign assets: Panel data evidence on the voracity effect, Journal of International Economics, Elsevier, 86(2), 318-326. doi: 10.1016/j.jinteco.2011.11.001

Auty R. (2001). The political economy of resource-driven growth. European Economic Review, 45, 839-46. https://econpapers.repec.org/RePEc:eee:eecrev:v:45:y:2001:i:4-6:p:839-846

BIS (2019). Monetary policy framework in EMEs: Inflation targeting, the exchange rate and financial stability. BIS Annual Economic Report, Chapter II, 31-53. https://www.bis.org/publ/arpdf/ar2019e2.pdf

Choi W. G., Sharma S., Stromqvist M. (2007). Capital flows, financial integration, and international reserves holding: the recent experience of emerging market and advanced economies. IMF Working Paper, WP/07/151, 1-36. doi.org/10.5089/9781451867152.001

Cihak M., Demirguc-Kunt A., Feyen E., Levine R. (2012). Benchmarking financial development around the world. World Bank Policy Research Working Paper, 6175, 1-32. https://doi.org/10.1596/1813-9450-6175

Claessens S., \& Laeven L. (2003). Financial Development, Property Rights, and Growth. Journal of Finance, 58, 24012436. https://doi.org/10.1046/j.1540-6261.2003.00610.x

Crowe C., \& Meade E. (2008). Central Banks Independence and Transparency: Evolution and Effectiveness. IMF Working Paper, WP/08/119, 1-30. https://doi.org/10.5089/9781451869798.001

Disyatat P. (2003). Rationalizing Asia's Foreign Reserves Build-up. Bank of Thailand Economic Monitor, Dec., 1-8. https://econpapers.repec.org/RePEc:eee:asieco:v:14:y:2003:i:3:p:389-418

Dooley M., Folkerts-Landau D., Garber P. (2003). An essay on the revived bretton woods system. NBER Working Paper, 9971, 1-48. doi: 10.3386/w9971

Dooley, M., Folkerts-Landau, D., \& Garber, P. (2004). The revived Bretton Woods system: the effects of periphery intervention and reserve management on interest rates and exchange rates center countries. NBER Working Paper, 10332, 1-52. doi:10.3386/w10332 
Dreher A., Vaubel R. (2009). Foreign exchange reserves and the political business cycle: a panel data analysis. Journal of International Money and Finance, 28(5), 755-775. doi:10.1016/j.jimonfin.2008.12.007

Durda, C. B., Mendoza, E., \& Terrones, M. (2007). Precautionary demand for foreign assets in sudden stop economies: an assessment of the new merchantilism. IMF Working Paper, WP/07/146, 1-54. https://doi.org/10.5089/9781451867107.001

European Central Bank. (2006). The accumulation of foreign reserves. ECB Occasional Paper, 43, 3-73. https://www.ecb.europa.eu/pub/pdf/scpops/ecbocp43.pdf

Gosselin, M.-A., \& Parent, N. (2005). An Empirical Analysis of Foreign Exchange Reserves in Emerging Asia. Bank of Canada Working Paper, 2005-38, 1-40. https://www.bankofcanada.ca/wp-content/uploads/2012/01/fsr1205-gosselin.pdf

Han I. (2006). The Political Economy of Reserve Accumulation in the Developing World. The Korean Journal of International Relations. 46(5), 231-248. doi:10.14731/kjis.2006.12.46.5.231

Hielscher K., Markwardt G. (2012). The Role of Political Institutions for the Effectiveness of Central Bank Independence. European Journal of Political Economy, 28(3), 286-301. doi:10.1016/i.ejpoleco.2011.08.004

Jager, K. (2016). The Role of Regime Type in the Political Economy of Foreign Reserves Accumulation. European Journal of Political Economy, 44, 79-96. doi:10.1016/j.ejpoleco.2016.05.001

Koziuk, V. (2016). Financial development, international exchange reserves and political regimes in commodity economies. Economic theory, 3, 82-102. (in Ukrainian) https://doi.org/10.15407/etet2016.03.082

Koziuk, V. (2016). Independence of Central Banks in Commodity Economies. Gerald of National Bank of Ukraine, 235 , 6-25. https://doi.org/10.26531/vnbu2016.235.006

Koziuk, V. (2018). Price stability and inflation targeting in commodity economies: macroeconomics vs political economy. Gerald of National Bank of Ukraine, 244, 4-25. https://doi.org/10.26531/vnbu2018.244.01

Kurronen, S. (2012). Financial Sector in Resource-Dependent Economies. BOFIT Discussion Papers,6, 1-35. https://doi.org/10.2139/ssrn.2027444

Leblang, D., \& Pepinsky, Th. (2008). To Have or to Hoard? The Political Economy of International Reserves. Paper Presented at the 2008 Annual Meetings of the American Political Science Association, Boston, M.A. https://courses.cit.cornell.edu/tp253/docs/ToHaveAndToHoard.pdf

McGrath, L. (2016). Insuring Against Past Perils: The Politics of Post-Currency Crisis Foreign Exchange Reserves Accumulation. Political Science Research and Methods, 5(3), 427-446. https://doi.org/10.1017/psrm.2016.9

Nurbayev, D. (2017). The Rule of Law, Central Bank Independence and Price Stability. Journal of Institutional Economics, 14(4), 659-687. https://doi.org/10.1017/S1744137417000261

Obstfeld M., Shambaugh J., Taylor A. (2008). Financial Stability, the Trilemma, and International Reserves. NBER Working Paper, 14217, 1-48. https://doi.org/10.3386/w14217

Rodrik D. (2006). The Social Cost of Foreign Exchange Reserves. NBER Working Paper, 11952, 1-24. https://doi.org/10.3386/w11952

Sanusi, K. A., Meyer, D. F., \& Hassan, A. S. (2019). An Investigation of the Determinants of Foreign Exchange Reserves in Southern Africa Countries. Journal of International Studies, 12(2), 201-212. https://doi.org/10.14254/2071-8330.2019/12-2/12

Son, B. (2020). Democracy and Reserves. Foreign Policy Analysis, 16(3), 417-437. https://doi.org/10.1093/fpa/orz020

Turner Ph., \& Mohanty, M. (2006). Foreign Exchange Reserve Accumulation in Emerging Markets: What Are the Domestic Implications? BIS Quarterly Review, Sept., 39-52. https://www.bis.org/publ/qtrpdf/r qt0609f.htm

Wijnholds, O., \& Sondergaard, L. (2007). Reserve Accumulation: Objective or By-Product? ECB Occasional Paper, 73 , 3-45. http:// citeseerx.ist.psu.edu/viewdoc/download?doi=10.1.1.165.6007\&rep=rep1\&type $=$ pdf

Wills, S., \& Van der Ploeg, R. (2014). Why do so many oil exporters peg their currency? Foreign reserves as a defacto sovereign wealth fund. Paper Presented at the joint RES-SPR Conference on "Macroeconomic Challenges Facing Low-Income Countries". IMF, Washington, D.C, Jan. 30-31. https://www.imf.org/external/np/seminars/eng/2014/lic/pdf/Ploeg1.pdf 